\title{
DEVELOPMENT OF SUNFLOWER HYBRIDS WITH DIFFERENT OIL QUALITY
}

\author{
Škorić, D. , Jocić, S., Lečić, N. and Sakač, Z.
}

Institute of Field and Vegetable Crops, Maksima Gorkog 30, 21000 Novi Sad, Serbia

Received: October 10, 2006 Accepted: May 15, 2007

\section{SUMMARY}

The cultivated sunflower (Helianthus annuus L.) is one of most important oil crops of the world. Although sunflower is primarily grown for extraction of its seed oil there is a limited production of non-oilseed sunflower types which are used in confections industry or as bird feed.

The objective of this research was development of hybrids with high and stable oleic acid content and modified tocopherol composition, with high values for the two most important agronomic characters (seed yield and oil yield) and high tolerance to Phomopsis.

The incorporation of the gene $\mathrm{Ol}+t p h_{1}$ into these genotypes has led to the development of high-oleic hybrids with altered tocopherol profiles. Oil of these hybrids has a much longer shelf-life than standard sunflower oil.

The process of incorporating the genes $\mathrm{Ol}+t p h_{2}$ and $\mathrm{Ol}+t p h_{1} t p h_{2}$ into highly productive sunflower genotypes is under way.

The most important results of this line of research are the newly developed female lines with the oleic acid content in oil over $90 \%$ and the male lines (restorers) with an oleic acid content in the $89-93 \%$ range. Using these lines, hybrids will be developed whose oleic acid content in oil will exceed $90 \%$.

Key words: sunflower, fatty acid content, cultivar VNIIMK 8931, tocopherol composition, breeding for oil quality, high oleic hybrids

\section{INTRODUCTION}

The sunflower is one of the most important oil crops globally and its oil is among the highest quality vegetable oils on the market. Oil quality is determined by the higher fatty acid composition and the levels of tocopherols, sterols, carotenoids, and other compounds. The sunflower is regarded as one of the most promising crops when it comes to the genetic alteration of oil quality (Scharp, 1986.). Standard sunflower oil is predominantly composed of linoleic acid (C-18:2) and oleic acid (C-18:1). These two acids account for about $90 \%$ of the total higher fatty acid con-

* Corresponding author: e-mail: skoricd@ifvens.ns.ac.yu 
tent of sunflower oil. The remaining $8-10 \%$ are comprised of palmitic and stearic acids (C-16:0 and C-18:0, respectively). Conventional sunflower oil also contains several other higher fatty acids, but these are usually found only in traces (C-14:0, C-16:1, C-14:1, C-20:0, C-22:0) (Friedt et al., 1994).

The first significant alteration of sunflower oil was carried out by Soldatov (1976), who treated the seed of the cultivar VNIIMK 8931 with a $2.5 \%$ solution of dimethyl sulphate (DMS) to obtain an induced mutation for a high oleic acid content, which he then used to develop the first high-oleic sunflower, Pervenec. Sunflower breeders worldwide have since used this cultivar as the source of genes for developing the present-day high-oleic hybrids of this crop. The mode of inheritance of high oleic acid content has been studied by a number of authors (Fick, 1984; Urie, 1985; Fernandez-Martinez et al., 1989; Demurin and Škorić, 1996, etc.). According to Fernandez-Martinez et al. (2004), different modes of inheritance of high oleic acid content have been reported, including partial dominance of a single gene, dominance of either one, two or three dominant genes, one dominant gene + one recessive gene acting as the modifier, a single recessive gene, etc. Molecular studies revealed a strong positive correlation between $\mathrm{D}^{12}$ RFLP and the high-oleic mutant (Lacombe et al., 2000).

Beside the genetic manipulation of the higher fatty acid composition, it is also possible to change the tocopherol composition of the sunflower oil. Standard sunflower oil is around 95\% $\alpha$-tocopherol, $3 \% \beta$-tocopherol, $2 \% \gamma$-tocopherol and trace amounts of $\delta$-tocopherol. Demurin (1988) selfed the cultivar VNIIMK 8931 to obtain an inbred line containing 50\% $\alpha$-tocopherol and 50\% $\beta$-tocopherol. The increased $\beta$ tocopherol content is controlled by a single recessive gene called $t p h_{1}$. In population 44 from the VIR gene bank, the same author discovered $t p h_{2}$, a recessive gene that controls increased $\gamma$-tocopherol content (5\% $\alpha$-tocopherol and 95\% $\gamma$-tocopherol). By combining these two recessive genes, Demurin (1993) obtained an inbred line with an increased $\delta$-tocopherol content (8\% $\alpha$-tocopherol, $84 \% \gamma$-tocopherol and $8 \%$ $\delta$-tocopherol).

Analyzing the achievements of sunflower breeding for different oil quality, Demurin et al. (1994), Demurin and Škorić (1995) and Škorić et al. (1996 and 1998) found positive synergy between genes for a high oleic acid and those for different tocopherol levels $\left(O l+t p h_{1} ; O l+t p h_{2} O l+t p h_{1} t p h_{2}\right)$. The objective of this paper was to examine the possibility of developing sunflower hybrids that combine different oleic acid levels with altered tocopherol composition, good agronomic characteristics and high tolerance to Phomopsis.

\section{MATERIALS AND METHODS}

In this study we used part of the breeding material developed at the Institute of Field and Vegetable Crops in Novi Sad during the 1993-2005 period. 
For donor lines of sunflower oil quality we chose inbred lines developed at VNIIMK, Krasnodar, Russia, namely:

1. B-lines: Lg-21 (Ol, $\left.t p h_{1}\right), \operatorname{Lg}-25\left(\mathrm{Ol}, t p h_{2}\right)$ and Lg-24 $\left(t p h_{1}, t p h_{2}\right)$

2. Rf-lines:VK-66-1 ( $\left.t p h_{1}, t p h_{2}\right)$, VK-66-2 $\left(O l, t p h_{1}\right)$ and VK-66-3 $\left(O l, t p h_{2}\right)$.

The donor lines of good GCA and SCA and high tolerance of Phomopsis were the following inbred lines developed at our Institute:

1. B-lines: Ha-74, Ha-981 and CMS-3-8

2. Rf-lines: RHA-583, RHA-576, RHA-SEL and RHA-SNRF-b.

In the first year of the study (1993), the above lines were subjected to crossing according to a system where each B-line tolerant to Phomopsis was crossed with each B-line donating quality and each $R f$-line tolerant of Phomopsis was crossed with each $R f$-line used as a donor of quality. In the autumn of 1993, under greenhouse conditions, backcrosses were made with the lines tolerant of Phomopsis and the hybrids were selfed to obtain the $\mathrm{F}_{2}$ generation. Plants used as the maternal component in the crosses were manually emasculated in the early morning hours before the anthers had opened. In the next phase, pedigree selection was used to develop inbreds with the desired characteristics, and conversion of the selected Blines into their cms variants was started in the summer of 1996. In the year 2000, testing began for general (GCA) and special (SCA) combining abilities by the line $\mathrm{x}$ tester method, while in 2003 the best hybrid combinations began to be tested in a network of small- and large-plot trials.

After harvest in each generation, individual plants were tested for tocopherol composition, oleic acid content, seed oil content and, in the case of generations grown under field conditions, for resistance to Phomopsis. Tocopherol content was determined by the half-seed method (Demurin, 1994) using thin-layer chromatography (TLC), while higher fatty acid composition and seed oil content were determined using gas chomatography (GS) and nuclear magnetic resonance (NMR), respectively. Tolerance to Phomopsis of the newly developed breeding materials was graded on a scale from 0 to 5 (0-resistant, 5-susceptible).

\section{RESULTS AND DISCUSSION}

The inbred lines developed at VNIIMK, Krasnodar, Russia, that were used in the present study as donors of oil quality $\left(\mathrm{Ol}, t p h_{1}\right.$ and $t p h_{2}$ genes), are characterized by poor agronomic traits, most notably by very high susceptability to Phomopsis. For this reason, they were crossed to inbreds developed at the Institute of Field and Vegetable Crops in Novi Sad characterized by very good agronomic characteristics and high tolerance of Phomopsis. One part of the $F_{1}$ generation obtained was subjected to selfing to produce the $\mathrm{F}_{2}$ generation, while another was backcrossed to the inbreds used as donors of resistance to Phomopsis. This way a starting popula- 
tion was developed for the selection of new inbred lines with different oil quality and a high tolerance of Phomopsis.

Each of the selfed generations was analyzed for increased oleic acid content in oil until this trait became completely stabilized, i.e., until the lines became homozygous for the trait. Additionally, each of the generations grown under field conditions was subjected to selection for resistance to Phomopsis and tests were done to determine tocopherol composition and seed oil content. Based on these results, new inbreds were developed with an increased oleic acid content and high tolerance towards Phomopsis.

Long-term work on sunflower oil quality conducted at Novi Sad Institute has produced significant results. Genes for high oleic acid content ( $O l$ genes) have been incorporated into a number of existing lines. In parallel with this, new genetic variability for increased oleic acid content has been created and new male and female lines with extremely high oleic acid levels have been developed. Compared with the existing high-oleic hybrid Olivko (75-85\%), the newly developed inbred lines have significantly higher oleic acid levels (89-93\%) (Table 1).

Table 1: Sunflower inbred lines with highest levels of oleic acid in oil

\begin{tabular}{llcccc} 
A) female lines \\
\hline No. & Genotype & Palmitic acid & Stearic acid & Oleic acid & Linoleic acid \\
\hline 1 & DOP-2 & 3.01 & 1.57 & 92.66 & 2.32 \\
2 & DOP-5 & 3.33 & 1.32 & 92.79 & 2.26 \\
3 & DOP-13 & 3.32 & 1.33 & 92.40 & 2.63 \\
4 & DOP-14 & 3.41 & 2.11 & 91.63 & 2.55 \\
5 & DOP-15 & 3.59 & 1.19 & 92.56 & 2.35 \\
6 & DOP-25 & 3.74 & 1.92 & 92.43 & 1.90 \\
7 & DOP-35 & 3.95 & 1.63 & 91.61 & 2.52 \\
8 & DOP-36 & 3.95 & 1.66 & 91.65 & 2.36 \\
9 & DOP-51 & 3.30 & 1.47 & 91.91 & 2.97 \\
10 & DOP-56 & 3.58 & 1.40 & 92.94 & 1.73 \\
\hline B) male lines & & & & \\
\hline No. & Genotype & Palmitic acid & Stearic acid & Oleic acid & Linoleic acid \\
\hline 1 & RHA-S-OL-9 & 4.10 & 3.53 & 89.28 & 2.46 \\
2 & RHA-S-OL-11 & 3.42 & 2.24 & 92.17 & 1.83 \\
3 & RHA-S-OL-12 & 4.28 & 2.26 & 91.80 & 1.41 \\
4 & RHA-S-OL-18 & 3.06 & 4.47 & 89.60 & 2.48 \\
5 & RHA-S-OL-21 & 3.46 & 4.52 & 89.78 & 1.81 \\
6 & RHA-S-OL-22 & 3.88 & 4.24 & 89.70 & 1.76 \\
7 & RHA-S-OL-23 & 3.48 & 3.82 & 89.77 & 2.59 \\
8 & RHA-S-OL-25 & 3.46 & 2.61 & 91.43 & 2.50 \\
9 & RHA-S-OL-26 & 3.48 & 3.62 & 90.04 & 2.24 \\
10 & RHA-S-OL-30 & 3.77 & 3.22 & 89.32 & 3.69 \\
\hline
\end{tabular}


Using these lines it is possible to rapidly develop new high-oleic (HO) sunflower hybrids. The only thing needed is to expediently convert the female (DOP) lines into their cms variants under field and greenhouse conditions using backcrosses. It is important to note that the male lines from this group have oleic acid levels ranging from 89 to $93 \%$ (Table $1 \mathrm{~B}$ ). Use of these materials most definitely makes it possible to quickly develop high-oleic sunflower hybrids with oleic acid levels of over $90 \%$ and use them for large-scale introduction into commercial production. According to preliminary studies of combining abilities of the above lines, the new high-oleic hybrids will have yields rivalling those of the highest-yielding sunflower hybrids currently in production. At the same time, these inbreds have been selected for resistance to a broad range of diseases, so the new high-oleic hybrids are going to have a high degree of resistance to the dominant diseases of sunflower.

The first cycle of breeding for oil quality has been completed at the Novi Sad Institute. The developed hybrids incorporate the $O l$ gene for a high oleic acid content and the $t p h_{1}$ gene for tocopherol content alteration (50\% alpha $+50 \%$ beta) (Table 2). The newly developed hybrids are as productive as NS-H-111, the most productive standard NS hybrid in existence. Several of these hybrids are currently undergoing registration and some of them are expected to enter commercial production within the next two years.

Table 2: Oleic acid and tocopherol contents in oil of new sunflower hybrids

\begin{tabular}{|c|c|c|c|c|c|c|}
\hline \multirow{2}{*}{ No. } & \multirow{2}{*}{ Designation } & \multirow{2}{*}{$\begin{array}{l}\text { Oleic acid } \\
\text { content \% }\end{array}$} & \multicolumn{4}{|c|}{ Tocopherol composition (\%) } \\
\hline & & & $\mathrm{a}$ & $\mathrm{b}$ & $\mathrm{g}$ & $\mathrm{d}$ \\
\hline 1 & NS-H-2031 & 78.56 & 100 & - & - & - \\
\hline 2 & NS-H-2032 & 81.13 & 100 & - & - & - \\
\hline 3 & NS-H-2033 & 81.30 & 50 & 50 & - & - \\
\hline 4 & NS-H-2034 & 82.47 & 50 & 50 & - & - \\
\hline 5 & NS-H-2072 & 80.34 & 50 & 50 & - & - \\
\hline 6 & NS-H-2073 & 82.56 & 50 & 50 & - & - \\
\hline 7 & NS-H-2074 & 83.37 & 50 & 50 & - & - \\
\hline 8 & NS-H-2075 & 81.90 & 50 & 50 & - & - \\
\hline 9 & NS-H-2076 & 82.29 & 50 & 50 & - & - \\
\hline 10 & NS-H-256 & 83.36 & 40 & 60 & - & - \\
\hline 11 & NS-H-2510 & 84.25 & 80 & 20 & - & - \\
\hline 12 & NS-H-2526 & 85.32 & 40 & 60 & - & - \\
\hline 13 & NS-H-2527 & 84.11 & 40 & 60 & - & - \\
\hline 14 & NS-H-2031 & 86.13 & 50 & 50 & - & - \\
\hline 15 & NS-H-9024 & 85.11 & 40 & 60 & - & - \\
\hline
\end{tabular}

Unfortunately, the breeding projects for incorporating $\mathrm{Ol}+t p h_{2}$ and $O l+t p h_{1} t p h_{2}$ genes into productive sunflower genotypes have not been finished yet. Inbred lines possessing these combinations of genes have not been fully fixed yet and the process of their development is still in progress. These projects are expected to be completed in a few years. Once they are completed, we will have new 
sunflower hybrids which combine high oleic acid content with either beta+gamma, gamma or gamma+delta tocopherols. Sunflower processors will be offerred new top quality sunflowers that can be used to obtain high-value final products from this crop.

\section{CONCLUSION}

Our breeding program for development of sunflower hybrids with different oil quality (1992-2005) has produced genotypes with high values of agronomically important traits:

A number of female lines with oleic acid levels of over $90 \%$ have been developed. At the same time, a number of restorer (male) lines have been developed with oleic acid levels in the $89-93 \%$ range. These lines are now being used to develop sunflower hybrids with an olec acid content of $90 \%$ and more.

$O l+t p h_{1}$ genes have been incorporated into a number of inbreds and hybrids have been developed that possess a high oleic acid content and ( $>80 \%)$ and altered tocopherol composition ( $50 \%$ alpha $+50 \%$ beta). The newly developed hybrids have considerably higher oil stability than the standard ones.

The incorporation of $\mathrm{Ol}+t p h_{2}$ and $\mathrm{Ol}+t p h_{1} t p h_{2}$ genes into productive sunflower genotypes is in progress.

\section{REFERENCES}

Demurin, Ya.N., 1988. Genetičskij analiz sastava tokoferolov v semenah podsolnečnika. Avtoreferat disertacije za KBN: 1-12.

Demurin, Ya.N., 1993. Genetic variability of tocopherol composition in sunflower seeds. Helia 16: 59-62.

Demurin, Ya., Škorić, D., Popov, P., Efimenko, S., \& Bochkovoy, A., 1994. Tocopherol genetics in sunflower breeding for oil quality. Proc. of EUCARPIA - Symposium on Breeding of Oil and Protein Crops. September 22-24, Albena, Bulgaria. pp. 193-197.

Demurin, Ya.N i Lečić Nada, 1994. Određivanje sastava tokoferola metodom "pola zrna" (in Serbian). Oil crops Production and Processing, The Book of articles from $35^{\text {th }}$ meeting of oil processing industry, May 24-27, Bar, Yugoslavia, 35: 255-258

Demurin, Ya., \& Škorić, D., 1995. Genetic modification of sunflower seed oil. Proc. of Symposium "Breeding and Cultivation of Wheat, Sunflower and Legume Crops in the Balkan Countries". June 26-29, Albena, Bulgaria, pp. 55-9.

Demurin, Ya.N., Škorić, D. and Karlović, D., 1996. Genetic variability of tocopherol composition in sunflower seeds as a basis of breeding for improved oil quality. Plant Breeding 115: 33-36.

Demurin, Ya., \& Škorić, D., 1996. Unstable expression of Ol genes for high oleic acid content in sunflower seeds. Proc. of $14^{\text {th }}$ Int. Sunflower Conference. June 12-20, Beiging/ Shenyang, China, 1: 145-151.

Fernadez-Martinez, J., Jimenez, A., Dominguez, J., Garcia, J.M., Garces, R. and Mancha, M., 1989. Genetic analysis of the high oleic acid content in cultivated sunflower (Helianthus annuus L.). Euphytica 41: 39-51.

Fernandez-Martinez, J.M., Velasco, L., Perez-Vich, B., 2004. Progress in the genetic modification of sunflower oil quality. Proc. of $16^{\text {th }}$ International Sunflower Conference. August 29-September 2, Fargo, North Dakota, USA. 1: 1-15.

Fick, G.N., 1984. Inheritance of high oleic acid in the seed oil of sunflower. Proc. Sunflower Research Workshop. Bismarck, ND. National Sunflower Association. pp. 9. 
Friedt, W., Ganssmann, M. \& Korell, M., 1994. Improvement of sunflower oil quality. Proc of EUCARPIA - Symposium on Breeding of Oil and Protein Crops. September 22-24, Albena, Bulgaria, pp. 1-30.

Lacombe, S., Berville, A., 2000. Problems and goals in studying oil composition variation in sunflower. Proc. of the $15^{\text {th }}$ International Sunflower Conference. June 12-15, Toulouse, France, 1: PI.D16-PI.D26.

Scharp, W.R., 1986. Opportunities for biotechnology in the development of new edible vegetable oil products. YAOCS 63(5): 594-600.

Soldatov, K.J., 1976. Chemical mutagenesis for sunflower breeding. Proc. $7^{\text {th }}$ Int. Sunflower Conference, Krasnodar, Russia. pp. 352-357.

Škorić, D., Demurin, Ya., \& Jocić, S., 1996. Development of hybrids with various oil qualities. Proc. $14^{\text {th }}$ International Sunflower Conference. June 12-20, Beiging/Shenyang, China, 1 : 54-60.

Škorić, D., Jocić, S., Lečić, N., 1998. Sunflower breeding for different oil quality. Genetics and Breeding for Crop Quality and Resistance. Kluwer Academic Publishers. Dordrecht/ Boston/London/. pp. 339-347.

Urie, L.A., 1985. Inheritance of high oleic acid in sunflower. Crop Science, (NovemberDecember) 25: 986-989.

\section{CREACIÓN DE HÍBRIDOS DE GIRASOL CON DIFERENTE CALIDAD DE ACEITE}

RESUMEN

El girasol cultivado (Helianthus annuus L.) es uno de los cultivos oleaginosos más importantes del mundo. Aunque el girasol se cultiva antes de todo para la producción de aceite, los tipos de girasol no oleaginosos, se cultivan en menor rango para la industria confitera y alimentos para pájaros.

El objetivo de esta investigación fue creación del híbrido con el contenido alto y estable de ácido oleico y contenido modificado de tocoferol, altos valores de dos características agronómicas más importantes (rendimiento de semilla y rendimiento de aceite) y alta tolerancia hacia Phomopsis.

La introducción de los genes $O l+t p h_{1}$ en esos genotipos, llevó hasta la creación de los híbridos altamente oleicos con diferentes contenidos de tocoferol. El aceite de esos híbridos se conserva mucho más tiempo que el aceite estándar de girasol.

$\mathrm{El}$ proceso de introducción de los genes $\mathrm{Ol}+t p h_{2}$ y $\mathrm{Ol}+t p h_{1} t p h_{2}$ en los genotipos de girasol altamente productivos, está en curso.

Los resultados más importantes de estas investigaciones son líneas maternas nuevas creadas con el contenido del ácido oleico por encima de $90 \%$ y líneas paternas (restauradores) con el contenido del ácido oleico en el rango entre 89 y $93 \%$. Utilizando estas líneas, pueden crearse híbridos con el contenido del ácido oleico en el aceite, por encima de $90 \%$.

\section{DÉVELOPPEMENT D'HYBRIDES DE TOURNESOL AVEC UNE QUALITÉ D'HUILE DIFFÉRENTE}

RÉSUMÉ

Le tournesol de culture (Helianthus annuus L.) est l'une des cultures oléagineuses les plus importantes du monde. Bien que le tournesol soit cultivé tout d'abord pour la production d'huile, des types de tournesol non oléagineux sont cultivés en plus petite quantité pour l'industrie de la confiserie et pour la nourriture des oiseaux. 
Le but de cette recherche était de créer un hybride ayant un contenu élevé et stable d'acide oléique et une composition modifiée du contenu de tocophérols, avec des valeurs importantes pour les deux caractéristiques agronomiques les plus importantes (rendement en graines et rendement en huile et avec une grande tolérance au Phomopsis.

L'incorporation du gène $\mathrm{Ol}+t p h_{1}$ dans ces génotypes a mené au développement d'hybrides à haute teneur oléique avec différents contenus de tocophérols. L'huile de ces hybrides se conserve beaucoup plus longtemps que les huiles de tournesol standard.

Le procédé d'incorporation de gènes $O l+t p h_{2}$ et de $O l+t h p_{1} t p h_{2}$ dans les génotypes de tournesol très productifs est en cours.

Les résultats les plus importants de cette recherche sont les lignées femelles nouvellement créées ayant un contenu d'acide oléique dans l'huile de plus de $90 \%$ et les lignées mâles de restauration ayant un contenu d'acide oléique sur une portée de 89 et $93 \%$. L'utilisation de ces lignées peut permettre la création d'hybrides ayant un contenu d'acide oléique dans l'huile de plus de $90 \%$. 